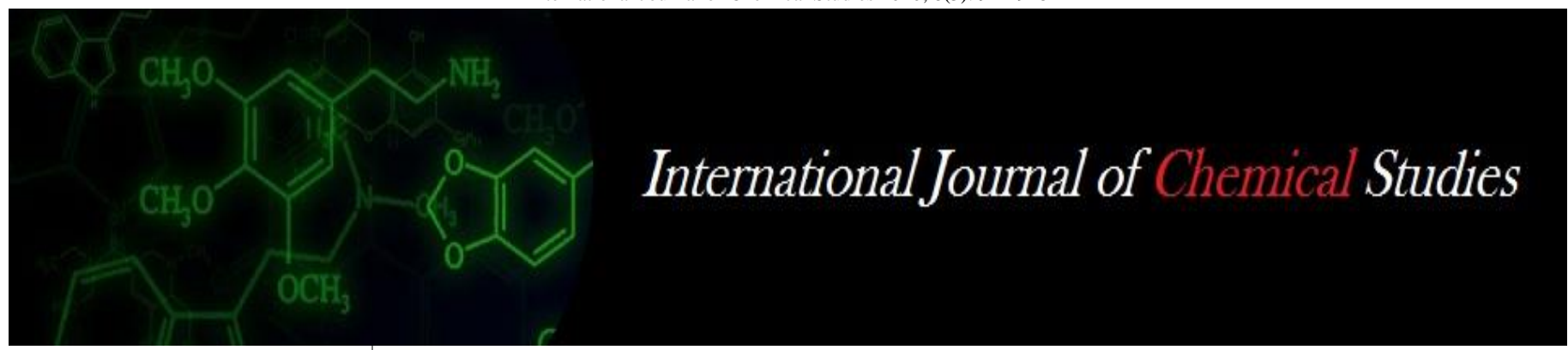

P-ISSN: 2349-8528

E-ISSN: 2321-4902

www.chemijournal.com

IJCS 2020; 8(3): 922-928

(C) 2020 IJCS

Received: 01-03-2020

Accepted: 03-04-2020

\section{Meenu Rani}

Division of Food Science and Technology, SKUAST-Jammu, FoA, Chatha, Jammu and

Kashmir, India

Monika Sood

Division of Food Science and Technology, SKUAST-Jammu, FoA, Chatha, Jammu and

Kashmir, India

\section{Julie D Bandral}

Division of Food Science and Technology, SKUAST-Jammu, FoA, Chatha, Jammu and Kashmir, India

\section{Anju bhat}

Division of Food Science and Technology, SKUAST-Jammu, FoA, Chatha, Jammu and

Kashmir, India

\section{Isha Gupta}

Division of Food Science and Technology, SKUAST-Jammu, FoA, Chatha, Jammu and Kashmir, India
Corresponding Author: Meenu Rani

Division of Food Science and Technology, SKUAST-Jammu, FoA, Chatha, Jammu and Kashmir, India

\section{Thermosonication technology and its application in food industry}

\author{
Meenu Rani, Monika Sood, Julie D Bandral, Anju bhat and Isha Gupta
}

DOI: https://doi.org/10.22271/chemi.2020.v8.i31.9317

\begin{abstract}
Nowadays, consumers prefer nutritious and safe food products having natural taste and freshness. It is known that traditional thermal techniques can extend the shelf life of food products and their safety, but they cause loss in nutritional parameters. Thermosonication (TS) is an emerging non thermal processing technique used for food. It is a combined method of thermosonication and heat. The product is subjected to ultra- sound and moderate heat simultaneously and they both together have some synergistic effect. Thermosonication is a form of energy generated by sound waves of frequencies that are greater than the upper limit of human hearing range, typically above $20 \mathrm{kHz}$. By coupling thermosonication with thermal treatment, increased levels of microbial kill can be achieved while minimizing changes to the organoleptic properties of foods. The advantages of sonoprocessing over thermal treatment are minimal flavour loss, significant energy saving and greater homogeneit. The process of thermosonication has been used for microbial and enzyme inactivation. This method produces a greater effect on inactivation of microorganisms than heat alone. When thermosonication is used for pasteurization or sterilization purpose, lower process temperatures and processing times are required to achieve the same lethality values as with conventional processes. It is also more efficient, safe and reliable than thermosonication application alone by itself to achieve the limit of food-borne pathogens destruction. Thermosonication is a valuable method to reduce the microbial load, saving cost and energy and being less aggressive against food properties than heat treatments alone. The enzymes and microbial inactivation by thermosonication treatment is attributed to heat and cavitation, which is the phenomenon of formation, growth and explosion of bubbles in a liquid. During implosion, very high temperatures (approximately $5000 \mathrm{~K}$ ) and pressures (estimated at $50000 \mathrm{kPa}$ ) are reached inside these bubbles. The explosion leads disruption of cell wall of micro-organisms causing their death. The process of thermosonication is used for extending the shelf life of liquid food like fruit juices.
\end{abstract}

Keywords: Thermosonication, food industry, nowadays

\section{Introduction}

Fruits are highly perishable and have to be processed into juices to ensure year-round continuous supply. The highest juice quality is required to meet consumer needs and juice safety aspects are important considerations for prolonging shelf life. Fruit juices are one of the food products which are thermally sensitive and susceptible to chemical, physical and microbiological changes. The processing methods may affect the quality and safety of the fruit juices. Today, the use of non-thermal food processing technologies is available to meet the demands of natural conventional fruit juices processing process is thermally inclined and results in some nutritional compounds loss such as flavonoids ${ }^{[13]}$ and carotenoids ${ }^{[12]}$ Its production efficiency is about 60 to $80 \%$ of fruit juice yield with rapid drop if old fruits are used. Risks of darker juice and containing excessive suspended solids and unwanted flavours also occur. It accounts for $90 \%$ of the total energy consumption ${ }^{[29]}$ and requires prolonged processing time of 15 to 45 minutes ${ }^{[16]}$. The usage of thermosonication as an alternative technology to the conventional fruit juices processing technologies has attracted interest of many for its benefits in decreasing processing time, reducing energy consumption, increasing efficiency and improving shelf life and quality of fruit juices. These improvements are possible due to the properties of instantaneous transfer of acoustic energy into fruit juices. The ultrasonic treatment can penetrate fruit cell walls and release cell contents trapped in the fruit tissues. Thermal preservation such as pasteurisation and sterilisation are commonly used to destroy microorganisms and inactivate enzymes in fruit juices. 
These extreme heat treatments at temperature of more than 80 ${ }^{\circ} \mathrm{C}$ may cause undesirable changes in various properties of fruit juices including physical, chemical, biological and organoleptic such as nutrients, colour and flavour ${ }^{[26]}$. The thermosonication technology, which combines moderate heat of 37 to $75^{\circ} \mathrm{C}$ with thermosonication treatment, is a potential alternative processing technique to enhance inactivation of enzymes and microbial ${ }^{[22]}$.

\section{Thermosonication}

is defined as sound waves having frequency that exceeds the hearing limit of the human ear $(\sim 20 \mathrm{kHz})$. It is one of the emerging technologies that were developed to minimize processing, maximize quality and ensure the safety of food products. Thermosonication is applied to impart positive effects in food processing such as improvement in mass transfer, food preservation, assistance of thermal treatments and manipulation of texture and food analysis ${ }^{[30]}$.

Thermosonication is versatile and innovative technology due to its wide range of application and increase in knowledge and research studies. It is used in food industry for many purposes including analysis methods and food processing such as freezing, cutting, drying, tempering, homogenization, degassing, antifoaming, filtration and extraction. Thermosonication can be used as a promoter or alternative to food processing. There may be numereous advantages of using thermosonication for food processing such as effective mixing, increased mass transfer, reduced energy, reduced temperature and increased production rate. Due to the elimination of microorganisms and enzymes without destroying nutrients of foods, thermosonication can be used as an alternative method to thermal treatments in the food preservation. Additionally, low power thermosonication is thought to be an attractive non-thermal method due to overcome problems which occur during heat treatments such as physical and chemical changes, nutritional loss and change in organoleptic properties ${ }^{[1]}$.

\section{Classification of ultrasonication}

In food industry ultraonication can be classified into two main categories on the basis of frequency range

- Low-power ultrasonication (from $100 \mathrm{kHz}$ and above) and

- $\quad$ High-power ultrasonication (from 20 to $100 \mathrm{kHz}$ )

Both of which have been used in the food industry. The food industry has been using low-power ultrasonication to assess the physicochemical properties of food products such as the composition and structure, and other quality control assessments ${ }^{[4]}$, while high-power thermosonication has been applied to a wide spectrum of applications that include sono crystallization, emulsification, drying and freezing processes, inactivation of enzymes such as pectin methylesterase, polyphenoloxidases and peroxidases responsible for deterioration of juices; modification of functional properties such as gelation, viscosity and solubility in proteins used at industrial levels (e.g. whey protein concentrate, soya protein isolate and egg white protein) ${ }^{[3]}$ and inactivation of microbes during decontamination and processing treatments. The application of power thermosonication requires the presence of a liquid phase.

\section{Ultrasound Generation}

Ultrasonic wave producing system contains the generator, transducer and the application system. Generator produces electrical or mechanical energy and transducer converts this energy into the sound energy at ultrasonic frequencies. Three main types of transducers are reported as fluid-driven, magnetostrictive and piezoelectric transducers.

The fluid-driven transducer produces vibration at ultrasonic frequencies by forcing liquid to thin metal blade which can be used for mixing and homogenization systems. The magnetostrictive transducer is made from a kind of ferromagnetic materials which change dimension upon the application of a magnetic field and these changes produce sought after mechanical vibrations. The efficiency of system is low somewhat $60 \%$ transfer to acoustic energy. The piezoelectric transducers produce acoustic energy by changes in size produced by electrical signals in piezoceramic materials such as lead zirconate titanate, barium titanate and lead metaniobate ${ }^{[27]}$. The piezoelectric transducers are most commonly used devices and are more efficient (80\%-95\% transfer to acoustic energy).

In application system a coupler device is used to transfer ultrasonic vibrations to the sample. This is generally obtained by ultrasonic bath and probe system. In ultrasonic baths, generally the transducers are fixed to the underside of the tank and most of the baths operated at around $40 \mathrm{kHz}$. In probe systems the horns or probes are used to transmit or to amplify the ultrasonic signal. Their lengths must be half the wavelengths, or multiple, to maintain the resonant conditions of the system. The horn shape defines the amplitude gain of ultrasonic signal. If the probe is the same diameter along its length then no gain in amplitude will occur but acoustic energy will be simply transferred to the media ${ }^{[21]}$.

\section{Methods of Ultrasonic Technology}

Thermosonication can be used for food preservation in combination with other treatments by improving its inactivation efficacy.

- Ultasonication (US) is the application of thermosonication at low temperature ${ }^{[35]}$.

- Thermosonication (TS) is a combined method of thermosonication and heat. The product is subjected to thermosonication and moderate heat simultaneously. This method produces a greater effect on inactivation of microorganisms than heat alone ${ }^{[33]}$.

- Manosonication (MS) is a combined method in which thermosonication and pressure are applied together. Manosonication provides to inactivate enzymes and/or microorganisms by combining thermosonication with moderate pressures (100 to $300 \mathrm{kPa}$ ) at low temperatures [9].

- Manothermosonication (MTS) is a combined method of heat, thermosonication and pressure. Applied temperature and pressure maximizes the cavitation or bubble implosion in the media which increase the level of inactivation. Microorganisms that have high thermo tolerance can be inactivated by manothermosonication ${ }^{[5]}$.

\section{Thermosonication}

The combination of thermosonication with temperature treatments is able to reduce the operating requirements (e.g. temperature levels and process times) while achieving a microbial inactivation similar to conventional heat treatments. Food properties such as shelf life and surface colour stability (lightness) in orange juice could be better enhanced, while organoleptic parameters could also be retained [23] Application of continuous $(24 \mathrm{kHz}, 400 \mathrm{~W}, 120 \mathrm{~lm})$ and pulsing thermosonication treatments (thermosonication 
conditions were same as described kpreviously with a cycle of $5 \mathrm{~s}$ on and $5 \mathrm{~s}$ off) at $60^{\circ} \mathrm{C}$ during $10 \mathrm{~min}$ in different juices (i.e. pineapple, cranberry and grape). All the continuous modes were more effective than pulsed modes in bacterial inactivation with the exception of cranberry juice, although the difference was not more than $1 \log$. All microbial kinetics of Saccharomyces cerevisiae for the tested juices showed tailing effects, indicating the presence of a resistant subpopulation, with an exception of grape juice treated by pulsed mode that showed a shoulder (i.e. initial resistance to the applied treatment) effect ${ }^{[15]}$. Reported the antagonistic effect of temperature was not detected due to the presence of solid elements in the milk suspension which increased the cavitation phenomena. The synergetic effect between thermosonication and heat can also be linked to the ability of thermosonication to produce nonlethal intracellular injuries, resulting in more vulnerable cells to heat treatments increasing their disruption rate. Overall, thermosonication is a valuable method to reduce the microbial load, saving cost and energy and being less aggressive against food properties than heat treatments alone. Nevertheless, high temperatures can produce an opposite effect as they can reduce the cavitation phenomena. Additionally, the enhancement of the sonication effects when treating suspensions containing solid particles indicates that liquid food products such as milk and juices when having solid particles are the most suitable for thermosonication.

\section{Basic Principle of Thermosonication}

Fig. 1 illustrates the formation, growth and collapse of bubbles during a cavitation phenomenon. Gas bubbles are produced in liquid media by ultrasonic waves prior to acoustic cavitation phenomenon, which is the interaction changes around the dissolved gas nuclei leads to oscillations, where the dissolved gas and solvent vapour disperse in and out of the oscillating bubbles. The quantity of gas and vapour that enters the bubbles during this expansion period is beyond the quantity that diffuses out of the bubbles during the compression stage of bubbles oscillations. The bubbles then grow in successive cycles to an unstable size, burst in the compression phase and release very high heat and pressure around the collapsing bubbles to break the compounds in the liquid and give localised sterilisation effect. At this point, particle dispersion and cell disruption occur between ultrasonic waves, liquid and dissolved gas when thermosonication passes through a liquid medium ${ }^{[27]}$.
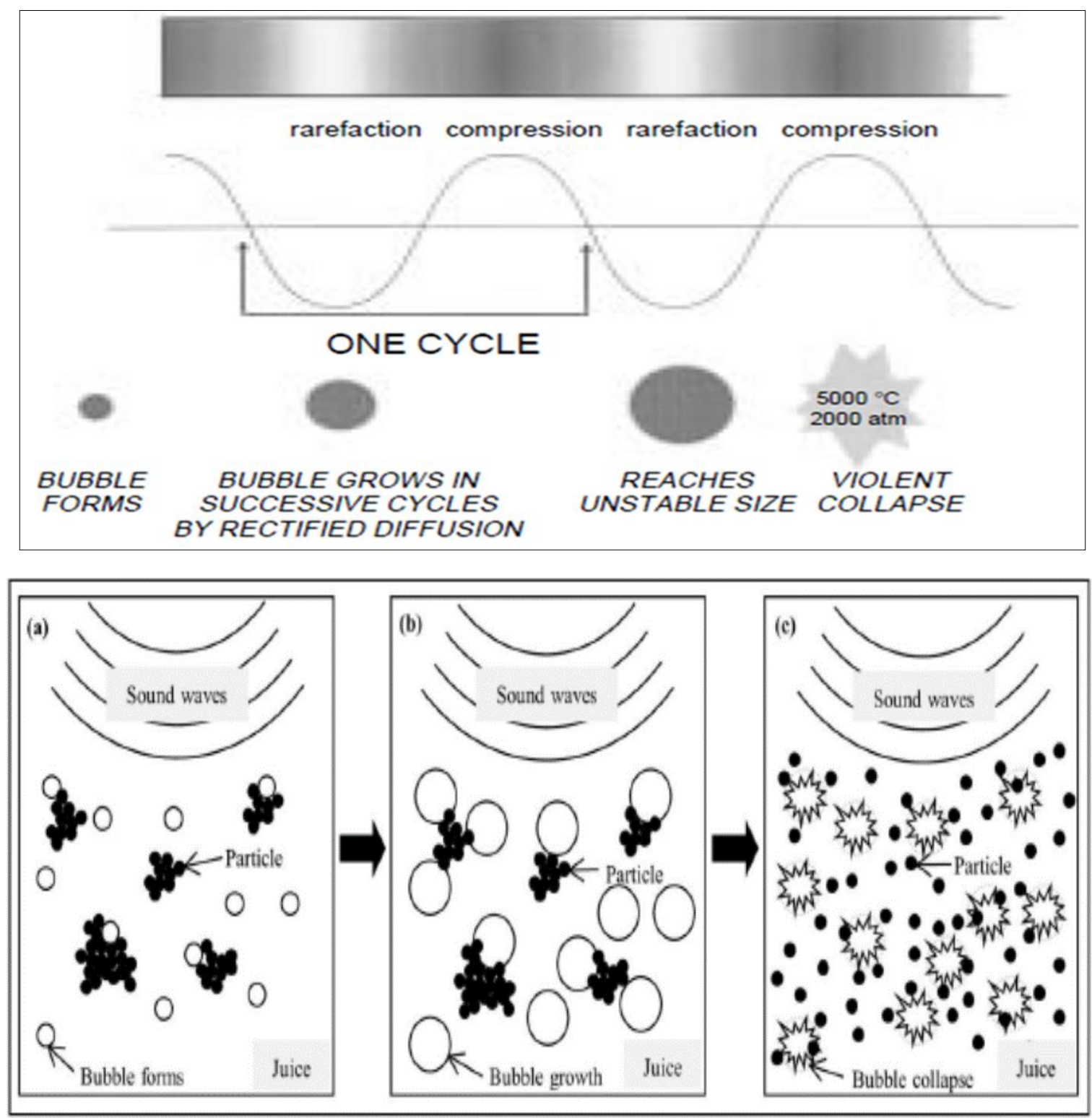

Fig 1: Cavitation phenomenon. (a) Bubbles formation in juice by sound waves; (b) bubbles growth to the maximum size and (c) bubbles collapse, and particle dispersion and cell disruption occurrence. 


\section{Mechanism of Action of Thermosonication Microbial Inactivation}

Microbial inactivation mechanisms of thermosonication is simply explained by cavitation phenomena that caused by the changes in pressure. Extremely rapid creation and collapse of bubbles formed by ultrasonic waves in a medium creates the antimicrobial effect of thermosonication. During the cavitation process, localized changes in pressure and temperature cause break- down of cell walls, disruption and thinning of cell membranes, and DNA damage via free radical production. Effect of thermosonication on microbial inactivation also depends on intensity and frequency of thermosonication applied. Generally, frequency range of 200 $600 \mathrm{kHz}$ enhanced the effects of thermosonication on microorganisms ${ }^{[8]}$. Showed that thermosonication treatment combined with mild heat $\left(57^{\circ} \mathrm{C}\right)$ for $18 \mathrm{~min}$. resulted in a 5$\log$ reduction of L. monocytogenes in milk, a 5-log reduction in total aerobic bacteria in raw milk, and a 6-log reduction in E. coli O157: $\mathrm{H} 7$ in pasteurized apple cider. High intensity ultra- sound to investigate inactivation of Enterobacteriae in raw milk. For thermosonications treatment, they used three parameters: temperature $\left(20^{\circ} \mathrm{C}, 40^{\circ} \mathrm{C}\right.$ and $\left.60^{\circ} \mathrm{C}\right)$, amplitude $(120,90$ and $60 \mu \mathrm{m})$ and time $(6,9 \text { and } 12 \mathrm{~min})^{[21]}$. They found that inactivation of microorganisms using ultra- sound depends on the amplitude of the ultrasonic waves, the exposure/contact time with the microorganisms, and the temperature of treatment. The achieved results indicate significant inactivation of microorganisms under longer period of treatments with ultrasonic probe particularly in combination with higher temperature and amplitude ${ }^{[29]}$.

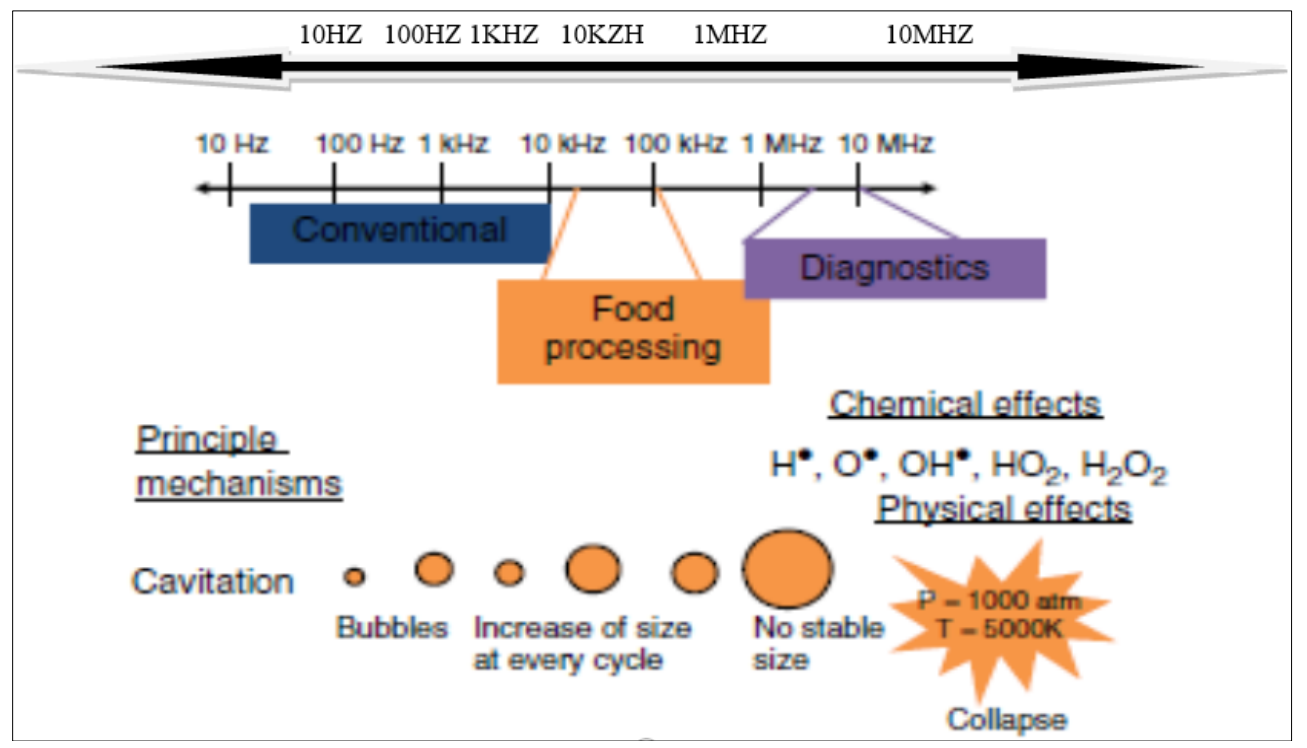

Fig 2: Thermosonication antimicrobial mechanism of action.

Table 1: Inactivation of microorganisms by using heat, ultrasound and pressure

\begin{tabular}{|cccccc|}
\hline \multirow{2}{*}{ Organism } & $\begin{array}{c}\text { Temperature } \\
\text { ('C) }\end{array}$ & Heat & Ultrasound & Thermosonication & $\begin{array}{c}\text { Manosonication/ } \\
\text { manothermosonication }\end{array}$ \\
\cline { 3 - 6 } & Ambient & - & 4.3 & - & $1.5(200 \mathrm{kPa})$ \\
Listeria monocytogenes & 30 & - & 1.52 & - & $1.0(400 \mathrm{kPa})$ \\
Yersenia entercolitica & 60 & 3.53 & 3.1 & 0.73 & $0.2(600 \mathrm{kPa})$ \\
Saccharomyces cerevisiae & 61 & 0.79 & 1.01 & 0.44 & - \\
Escherichia coli K12 & 56 & 0.86 & - & - & $0.40(300 \mathrm{kPa})$ \\
Cronabacter sakazakii & 55 & 17.40 & - & 5.06 & 0.28 \\
Aspergillus flavis & 60 & 2.60 & - & 1.20 & - \\
Penicillium digitatum & 50 & 25.42 & - & 9.59 & - \\
Listeria innocua & 63 & 30 & - & 10 & - \\
Lactobacillus acidophilus & 60 & 70.5 & - & 43.3 & - \\
Enterecoccus faecium & 62 & 11.2 & 30 & 1.8 & - \\
Staphylococcus aureus & 50.5 & 19.7 & - & 7.3 & - \\
\hline
\end{tabular}

\section{Enzymes Inactivation}

First enzyme inactivation by thermosonication was applied to pure pepsin almost 60 years ago and its inactivation mechanism was explained by cavitation. Since then, it has been proven that thermosonication is an effective method in the inactivation of enzymes when it is used alone or with temperature and pressure. There are many enzymes inactivated with thermosonication such as glucose oxidase, peroxidas ${ }^{[8,11]}$ pectin methyl esterase, protease and lipase, watercress peroxidase and polyphenoloxidase. Table 2 summarizes the thermosonication application on enzymes. Thermosonication creates continuous vibration and produce 
stable cavitation bubbles which collapse due to the ex- treme local increase in pressure (1000 P) and temperature $(5000 \mathrm{~K})$. Also, because of shock waves strong shear and microstreaming the adjacent liquid is observed. All of these factors can cause modification of secondary and tertiary structure of protein due to the breakdown of hydrogen bonding or Van der Walls interaction in the polypeptide chains. These changes cause activity loss of many enzymes. The extreme pressure and temperature also lead to homolytic water molecule cleavage generating high energy intermediates such as hydroxyl and hydrogen free radicals. The free radical formed may react with some amino acid residues that participate in enzyme stability, substrate binding or in the catalytic function with a consequent change in biological activity. Such free radicals could recombine with amino acid residues of the enzymes. These residues are associated with structure stability, substrate binding and catalytic functions. Distruption of tissue due to the ultrasonic application is an important criterion. As the amount of distruption tissue increases, surface area that contact with the enzymes and free radicals increases. For example, oxidases are usually inactivated by sonication while catalyses are affected at low concentration [22].

Table 2: Inactivation of enzymes by using heat, pressure and ultrasound treatments.

\begin{tabular}{|c|c|c|c|}
\hline Enzyme & Mediun & Treatment & Effect on activity \\
\hline $\begin{array}{l}\text { Pectinmethylesterase } \\
\text { (PME) and } \\
\text { Polygalacturanase } \\
\text { (PG) }\end{array}$ & Phosphate buffer & $\begin{array}{c}20 \mathrm{kHz}, 52^{\circ} \mathrm{C}-86^{\circ} \mathrm{C}, \\
12-45 \mathrm{~kg} / \mathrm{cm}^{2}, 0-104 \mu \mathrm{m}\end{array}$ & $\begin{array}{l}\text { PME; } D_{62.5} \mathrm{C}=45 \mathrm{~min} \text { decreased to } 0.85 \mathrm{~min} \\
\text { by MTS } \\
\text { PGI; } D_{866^{\circ} \mathrm{C}}=20.6 \mathrm{~min} \text { decreased to } 0.24 \mathrm{~min} \\
\text { by MTS } \\
\text { PGII; } D_{52.5^{\circ} \mathrm{C}}=38.4 \text { decreased to } 1.46 \mathrm{~min} \text { by MTS }\end{array}$ \\
\hline Egg white lysozyme & $\begin{array}{l}\text { Phosphate buffer } \\
\text { (pH 6.2) }\end{array}$ & $\begin{array}{c}20 \mathrm{kHz}, 50^{\circ} \mathrm{C}-80^{\circ} \mathrm{C} \\
200 \mathrm{kPa}, 117 \mu \mathrm{m}\end{array}$ & $\begin{array}{l}\text { Application of external pressure and temperatures } \\
\text { increased the inactivating effect of ultrasound. }\end{array}$ \\
\hline $\begin{array}{l}\text { Glucose-6-phosphate } \\
\text { dehydrogenase }\end{array}$ & $\begin{array}{l}\text { Distilled water } \\
\qquad(\mathrm{pH}=5.6)\end{array}$ & $\begin{array}{c}27 \mathrm{kHz}, 60 \mathrm{~W} / \mathrm{cm}^{2}, 36^{\circ} \mathrm{C}-47^{\circ} \mathrm{C} \\
880 \mathrm{kHz} \text { and } 1 \mathrm{~W} / \mathrm{cm}^{2} \\
36^{\circ} \mathrm{C}-47^{\circ} \mathrm{C}\end{array}$ & $\begin{array}{l}\text { Caused higher inactivation as compared to thermal } \\
\text { treatment, dependent on enzyme concentration, } \\
\text { higher activation energy at lower frequency and } \\
\text { substantial effect of free radical scavengers; } \\
\text { substrate and co-factor of the enzyme had a } \\
\text { protective effect against ultrasound inactivation. }\end{array}$ \\
\hline $\begin{array}{l}\text { Orange juice pectin } \\
\text { mehylesterase (heat } \\
\text { resistant fraction) }\end{array}$ & $\begin{array}{l}\text { Citrate buffer } \\
\text { and orange juice }\end{array}$ & $\begin{array}{c}20 \mathrm{kHz}, 33^{\circ} \mathrm{C} \text { and } 72^{\circ} \mathrm{C} \\
200 \mathrm{kPa}, 117 \mu \mathrm{m}\end{array}$ & $\begin{array}{l}\text { MTS increased the inactivation by } 25 \text { times in } \\
\text { citrate buffer and }>400 \text { times in orange juice. } \\
\text { Synergistic effect of heat and ultrasonics on the } \\
\text { thermostable PME. }\end{array}$ \\
\hline Catalase & $\begin{array}{l}\text { Buffer } \\
\text { (pH 4.15) }\end{array}$ & $\begin{array}{c}20.8 \mathrm{kHz}, 48-62 \mathrm{~W} / \mathrm{cm}^{2} \\
2.64 \mathrm{MHz}, 0.05-1.0 \mathrm{~W} / \mathrm{cm}^{2}\end{array}$ & $\begin{array}{l}\text { Inactivation rate increased with power, decreased } \\
\text { with enzyme concentration and varied with } \mathrm{pH} \text { : } \\
\text { higher inactivation by ultrasound was obtained at } \\
\text { higher frequency, free radiacals assumed play a } \\
\text { role in inactivation. }\end{array}$ \\
\hline $\begin{array}{l}\text { Catalase from yeast, } \\
\text { fungus and bovine }\end{array}$ & $\begin{array}{l}\text { Phosphate buffer } \\
\text { (pH } 7.4 \text { or } 5.5 \text { ) }\end{array}$ & $\begin{array}{l}27 \mathrm{kHz}, 60 \mathrm{~W} / \mathrm{cm}^{2} \\
45^{\circ} \mathrm{C} \text { and } 50^{\circ} \mathrm{C}\end{array}$ & $\begin{array}{l}\text { Catalase exhibited the following rank order of } \\
\text { resistance to ultrasonic inactivation: } \\
\text { fungal catalase }>\text { bovine }>\text { yeast. }\end{array}$ \\
\hline $\begin{array}{l}\text { PME and (PG) of } \\
\text { tomato paste }\end{array}$ & $\begin{array}{l}\text { Tomato pure } \\
(5.5 \% \text { solid) }\end{array}$ & $20 \mathrm{kHz}, 200 \mathrm{kPa}, 70^{\circ} \mathrm{C}, 117 \mu \mathrm{m}$ & $\begin{array}{l}100 \% \text { inactivation of } \mathrm{PME}, 62 \% \text { inactivation of } \\
\mathrm{PG} \text {. }\end{array}$ \\
\hline Lipase and protease & $\begin{array}{l}\text { Phosphate buffer } \\
\text { (pH } 5.5-8.0 \text { ) }\end{array}$ & $\begin{array}{c}20 \mathrm{kHz}, 350-600 \mathrm{kPa} \\
110^{\circ} \mathrm{C}-140^{\circ} \mathrm{C}, 60-150 \mu \mathrm{m}\end{array}$ & $\begin{array}{l}\text { Decreased activity in both enzymes. Effect of } \\
\text { amplitude was different depending on } \\
\text { temperature. Lipase inactivation by MTS depends } \\
\text { on } \mathrm{pH} \text {. }\end{array}$ \\
\hline $\begin{array}{l}\text { Tomato peroxidase } \\
\text { (POD) }\end{array}$ & $\begin{array}{l}\text { Acetate buffer } \\
\quad(\mathrm{pH} 5.0)\end{array}$ & $23 \mathrm{kHz}, 63^{\circ} \mathrm{C}-67^{\circ} \mathrm{C}, 3-15 \mu \mathrm{m}$ & $\begin{array}{l}\text { Activity of tomato POD decreased with rise of } \\
\text { ultrasonic power and time. }\end{array}$ \\
\hline Peroxidase & $\begin{array}{l}\text { Phosphate buffer } \\
\text { (pH 7.0) }\end{array}$ & $20 \mathrm{kHz}, 371 \mathrm{~W} / \mathrm{cm}^{2}, 20^{\circ} \mathrm{C}$ & $\begin{array}{l}\text { Original enzyme activity was reduced by } 90 \% \\
\text { over a } 3 \text { hour period. }\end{array}$ \\
\hline
\end{tabular}

\section{Advantages of Thermosonication}

Thermosonication applications offer numerous advantages in the food industry some of which are enlisted as follows:

- Thermosonication waves are non-toxic, safe, and environmentally friendly ${ }^{[19]}$.

- Thermosonicationin combination with other non-thermal methods is considered an effective means of microbial inactivation ${ }^{[32]}$.
- Thermosonication involves lower running cost, ease of operation, and efficient power output.

- Thermosonication does not need sophisticated machinery and wide range of technologies

- Use of thermosonication along with moderate heat provides more yield and rate of extraction as compared to other conventional methods of extraction. 
- Thermosonication and mild heat involves minimum loss in flavor, superior consistency (viscosity, homogenization) and significant savings in energy expenditure ${ }^{[6]}$.

- Thermosonication has gained huge applications in the food industry such as processing, extraction, emulsification, preservation, homogenization, etc.

- Thermosonication mainly used to inactivate the enzymes in fruit juices e.g. Pectinmethylestrases.

\section{Disadvantages}

Despite having lot of advantages, use of thermosonication has also many disadvantages such as:

- Thermosonication due to shear stress developed by swirls from the shock waves (mechanical effects) cause inactivation of the released products ${ }^{[20]}$.

- Thermosonication application needs more input of energy which makes industrialists to think over while using this technique on commercial scale ${ }^{[34]}$.

- Thermosonication induces physicochemical effects which may be responsible for quality impairment of food products by development of off-flavors, alterations in physical properties, and degradation of components.

- Thermosonication leads to the formation of radicals as a result of critical temperature and pressure conditions that are responsible for changes in food compounds. The radicals $(\mathrm{OH}$ and $\mathrm{H})$ produced in the medium deposit at the surface of cavitation bubble that stimulates the radical chain reactions which involve formation of degradation products and thus lead to considerable quality defects in product ${ }^{[7]}$.

- Frequency of thermosonication waves can impose resistance to mass transfer ${ }^{[10]}$.

- Thermosonication power is considered to be responsible for change in materials based on characteristics of medium.

\section{Applications of Thermosonication}

- Thermosonication treatment method is able to inactivate the enzymes and destroy the microorganisms ${ }^{[11]}$.

- At lower temperature and shorter time to give lower losses of ascorbic acid, total phenolics, flavonoids and flavonols ${ }^{[2]}$.

- Thermosonication decrease the required processing temperature and time, in pasteurization of liquid foods like milk, wine, and juices. It is used as a substitute or additional process to traditional thermal methods.

- Numerous other applications of thermosonication are reported in several foods including, cooking oils, bread, cereal products, and emulsified fat-based food products, food gels, aerated foods, and frozen foods.

- It has also been used to determine the interaction of powder with solvent in order to evaluate the reconstitution of powders.

- It used in the food processing industries for preparation of additive and preservative free quality fruit juices ${ }^{[1]}$.

\section{Conclusion}

The demand for higher quality and freshness in fruit juices with absence of additives and preservatives has encouraged the use of ultrasound technology in juice processing. Thermosonication is a novel and good alternative technique to replace the conventional heat treatment process. It has potential in enhancing quality and safety of the fruit juices. It is more energy-efficient than conventional thermal technology. It is also more efficient, safe and reliable than ultrasound application alone by itself to achieve the limit of food-borne pathogens destruction. The simultaneous application of ultrasound and mild heat in fruit juice processing industry has the greatest potential and numerous benefits of juice quality preservation and safe processing. The cavitation effects of ultrasound functions to reduce juice yield, ascorbic acid content and colour loss and gives improvement in terms of the enzymes inactivation and microbial destruction. For a shorter processing time, it can be categorized as minimal processing for freshness and health purposes.

\section{References}

1. Abdullah N, LingChin N. Application of thermosonication treatment in processing and production of high quality and safe-to-drink fruit juices. Agriculture and Agricultural Science Procedia. 2014; 2:320-327.

2. Abid M, Jabbar S, Hu B, Hashim MM, Wu T, Lei S, Khan MA et al. Thermosonication as a Potential Quality Enhancement Technique of Apple Juice. Ultrasonics Sonochemistry. 2014; 21(3):984-990.

3. Arzeni C, Mart inez K, Zema P, Arias A, Perez O, Pilosof A. Comparative study of high intensity thermosonication effects on food proteins functionality. Journal of Food Engineering. 2012; 108:463 472.

4. Awad T, Moharram H, Shaltout O, Asker D, Youssef M. Applications of thermosonication in analysis, processing and quality control of food: a review. Food Research Intstitute. 2012; 48:410-427.

5. Chemat F, Zill-E-Huma, Khan MK. Applications of thermosonication in food technology: processing, preservation and extraction. Ultrasonic Sonochemistery. 2001; 18:813-835.

6. Chouliara E, Georgogianni KG, Kanellopoulou N, Kontominas MG. Effect of ultrasonication on microbiological, chemical and sensory properties of raw, thermized and pasteurized milk. International Dairy Journal. 2010; 20:307-313.

7. Czechowska-Biskup R, Rokita B, Lotfy S, Ulanski P, Rosiak JM. Degradation of chitosan and starch by 360$\mathrm{kHz}$ ultrasound. Carbohydrate Polymers. 2005; 60:175184. http://dx.doi.org/10.1016/j.carbpol.2004.12.001

8. Damico DJ, Silk TM, Wu JR, Guo MR. Inactivation of microorganisms in milk and apple cider treated with ultrasounds. Journal of Food Protection. 2006; 69(3):556563.

9. Ercan SS, Soysal C. Use of thermosonication in food preservation. Natural Science. 2013; 5(8):5-13.

10. Esclapez MD, García-Pérez JV, Mulet A, Cárcel JA. Ultrasound-assisted extraction of natural products. Food Engineering Reviews. 2011; 3:108-120.

11. Fonteles TV, Costa MGM, de Jesus ALT, de Miranda MRA, Fernandes FAN, Rodrigues S. Power Ultrasound Processing of Cantaloupe Melon Juice: Effects on Quality Parameters. Food Research International. 2012; 48(1):41-48.

12. Fratianni A, Cinquanta L, Panfili G. Degradation of carotenoids in orange juice during microwave heating. Food Science and Technology. 2010; 43(6):867-871.

13. Gennaro L, Cavella S, Romano R, Masi P. The use of ultrasound in food technology $\mathrm{I}$ : Inactivation of peroxidase by thermosonication. Journal of Food 
Engineering. 1999; 39:401-407. doi:10.1016/S02608774(99)00028-X

14. Ghosh S. Thermosonicationas an upcoming technology in the dairy industry. Journal of Advance Dairy Research. 2007; 5:3

15. Herceg Z, Re_zek Jambrak A, Lelas V, Mededovic Thagard S. The effect of high intensity thermosonication treatment on the amount of Staphylococcus aureus and Escherichia coli in milk. Food Technology and Biotechnology. 2012; 50:46.

16. Horváth-Kerkai E. Manufacturing fruit beverages, in Handbook of Fruits and Fruits Processing. In: Hui, Y.H., Barta, J., Cano, M.P., Gusek, T., Sidhu, J.S. and Sinha, N. (First Edition). Blackwell Publishing, Iowa, USA, 2006, 211.

17. Igual M, García-Martínez E, Camacho MM, MartínezNavarrete N. Changes in flavonoid content of grapefruit juice caused by thermal treatment and storage. Innovative Food Science and Emerging Technologies. 2011; 12(2):153-162.

18. Juraga E, Salamon BS, Herceg Z. Application of high intensity ultrasound treatment on Enterobacteriae count in milk. Mljekarstvo. 2011; 61:125-134.

19. Kentish S, Ashokkumar M. The physical and chemical effects of ultrasound. Thermosonication technologies for food and bioprocessing, 2011, 1-12.

http://dx.doi.org/10.1007/978-1-4419-7472-3

20. Lateef A, Oloke JK, Prapulla SG. The effect of ultrasonication on the release of fructosyltransferase from Aureobasidium pullulans CFR 77. Enzyme and Microbial Technology. 2007; 40:1067-1070.

21. Leadley CE, Williams A. Pulsed electric field processing, power thermosonication and other emerging technologies. In: Brennan, J.G., Ed., Food Processing Handbook, Wiley-VCH, Weinheim, 2006, 214-218.

22. Lee H, Kim H, Cadwallader KR, Feng H, Martin SE. Sonication in combination with heat and low pressure as an alternative pasteurization treatment-effect on Escherichia coli k12 inactivation and quality of Apple cider. Ultrasonics Sonochemistry. 2013; 20(4):11311138.

23. Lopez-Malo A, Palou E, Jimenez-Fernandez M, Alzamora SM, Guerrero S. Multifactorial fungal inactivation combining thermosonication and Antimicrobials. Journal of Food Engineering. 2005; 67:87-93.

24. Marx G, Moody A, Bermúdez-Aguirre D. A comparative study on the $m$ structure of Saccharomyces cerevisiae under nonthermal technologies: High hydrostatic pressure, pulsed electric fields and thermo-sonication. International Journal of Food Microbiology. 2011; 151:327-337.

25. Mason TJ. Power ultrasound in food processing: The way forward. In: Povey MJW, Mason TJ, Eds., Ultrasound in Food Processing, Blackie Academic and Professional, London, 1998, 105-126.

26. Mena P, Vegara S, Martín N, García-Viguera C, Saura D, Valero M. Changes on indigenous microbiota, colour, bioactive compounds and antioxidant activity of pasteurised pomegranate Juice. Food Chemistry. 2013; 141(3):2122-2129.

27. Mulet A, Carcel J, Benedito C, Rossello C, Simal S. Ultrasonic mass transfer enhancement in food processing. Transport Phenomena of Food Processing, Chapter 18, Boca Raton, 2003.
28. Patist A, Bates D. Ultrasonic innovations in the food industry: from the laboratory to commercial production. Innovative Food Science Emerging. 2008; 9:147-154.

29. Sandhu KS, Minhas KS, Sidhu JS. Processing of Citrus Juices, in Handbook of Fruits and Fruit Processing. In: Sinha, N., Sidhu, J., Barta, J., Wu, J. and Cano, M.P. (Second Edition). Wiley-Blackwell, Iowa, USA, 2012, 510.

30. Sunandita Ghosh. Thermosonicationas an upcoming technology in the dairy industry: An overview. Advances in Dairy Research. 2007; 5:3.

31. USDA. Kinetics of microbial inactivation for alternative food processing technologies: Ultrasound. US Food and Drug Administration Report, 2000.

http://www.fda.gov/Food/FoodScienceResearch/SafePrac ticesforFoodProcesses/ucm 103342.htm

32. Vercet A, Sánchez C, Burgos J, Montanés L, Lopez Buesa PL. The effects of manothermosonication on tomato pectic enzymes and tomato paste rheological properties. Journal of Food Engineering. 2002; 53:273278. http://dx.doi.org/10.1016/S0260-8774(01)00165-0

33. Villamiel $M$, de Jong $P$. Influence of high-intensity thermosonication and heat treatment in continuous flow on fat, proteins, and native enzymes of milk. Journal of Agriculture and Food Chemistry. 2000; 48:472-78.

34. Yusaf T, Al-Juboori RA. Alternative methods of microorganism disruption for agricultural applications. Applied Energy. 2014; 114:909-923.

35. Zheng L, Sun DW. Innovative applications of power thermosonication during food freezing processes -A review. Trends in Food Science \& Technology. 2006; 17(1):16-23. 